UDK 582.675.1:575(497.6)

\title{
CONTRIBUTION TO MOLECULAR GENETIC CHARACTERIZATION OF HELLEBORUS MULTIFIDUS Vis. IN BOSNIA AND HERZEGOVINA
}

\author{
Doprinos molekularno genetičkoj karakterizaciji Helleborus multifidus Vis. u Bosni i \\ Hercegovini
}

Lejla Lasić ${ }^{1}$, Semir Dorić ${ }^{1}$, Jasna Hanjalić ${ }^{1,}$ Jasmina C̆akar $^{1}$, Belma Kalamujić Stroil ${ }^{1}$, Gabrijela Radosavljević $^{1}$, Naris Pojskić ${ }^{1}$

\begin{abstract}
Helleborus multifidus Vis. is endemic Illyric-Adriatic species with distribution range in Italy, Slovenia, Croatia, Bosnia and Herzegovina, Montenegro and Albania. Although few studies reported different taxonomic categories for $H$. multifidus, this one is the first using molecular-genetic markers (trnL region and $m a t \mathrm{~K}$ of chloroplast DNA and nuclear ITS1 and ITS2 region) for genetic characterization of $H$. multifidus presented at three localites in Bosnia and Herzegovina. The results revealed that PCRRFLP on $\operatorname{trnL}$ intron was not informative for testing inter- or intrapopulation diversity. Contrary, analysis of matK, ITS1 and ITS2 sequences showed differences between populations from Trebinje region and Kupreško polje, pointing to the need to include additional analyses in order to confirm these findings.
\end{abstract}

Key words: Helleborus multifidus, trnL, matK, ITS1, ITS2

\section{INTRODUCTION - Uvod}

The genus Helleborus L. is a small genus of the family Ranunculaceae and includes perennial herbaceous species with rhizomes or erect, rather woody stems and digitate or pedate leaves. The inflorescences are different type of cymes with large flowers composed of five perianth segments (TUTIN, 1996). Species of the genus are widespread in Europe and western Asia, with the disjunction of $H$. thibetanus, distributed in East Asia (ZONNEVELD, 2001). The Balkans is considered the centre of the genus diversification with the highest number of species in the peninsula (SUN ET AL., 2001).

The genus is traditionally divided into two subgenera, Helleborus and Helleborastrum Spach., with six sections. Albeit, molecular phylogenetic investigations support the existence of six monophyletic sections, the subgeneric division is not recognized (SUN ET AL., 2001). The classification scheme is based on morphology, pollen and seed morphology, hybridization capability and nuclear DNA content (ZONNEVELD, 2001; MEINERS ET AL., 2011). The taxonomic resolution of many

${ }^{1}$ University of Sarajevo - Institute for Genetic Engineering and Biotechnology 
species is still the matter of debate among taxonomists. All species having distinct morphology are also distinctive in terms of molecular divergence (SUN ET AL., 2001). However, the relationships between the poorly differentiated species in section Helleborastrum are still not resolved (SUN ET AL., 2001).

The number of species and subspecies varies from 11 species (TUTIN, 1996), 15 species and 10 subspecies (MATHEW, 1989; ZONNEVELD, 2001) to 22 species based on recent taxonomic reviews (MEINERS ET AL., 2011). All these classifications were based on different methods and require further taxonomic clarification.

Helleborus multifidus Vis. is endemic Illyric-Adriatic species with distribution range in Italy, Slovenia, Croatia, Bosnia and Herzegovina, Montenegro and Albania (MARTINIS, 1973). The Catalogue of life recognizes three subspecies (H. multifidus ssp. hercegovinus (Martinis) B. Mathew, H. multifidus ssp. laxus (Host) Martinis and H. multifidus ssp. multifidus within the complex of $H$. multifidus (ROSKOV ET AL., 2017). However the H. multifidus taxon shows an extreme polymorphy of morphological characters and includes many other 'microspecies' (ZONNEVELD, 2001; MEINERS ET AL., 2011). It mostly grows on calcareous and dolomite soils, having a wide altitudinal range, from coastal to inland higher mountain habitats. It is a typical element of thermophyllous forests from the Quercetalia pubescentis, Erico-Pinetalia orders, and various other shrub formations, rocky meadows (ŠILIĆ, 1990).

The aim of this study was genetic characterization of $H$. multifidus collected at three localities in Bosnia and Herzegovina using molecular variation of $t r n \mathrm{~L}$ region of chloroplast DNA, matK, ITS1 and ITS2 markers.

\section{MATERIAL AND METHODS - Materijal i metode}

\section{Sampling of plant material - Uzorkovanje biljnog materijala}

Plant material of 110 hellebore specimens was collected during the plant flowering phase (April-June 2015) from three different localities in Trebinje region (locality $1-43^{\circ} 09^{\prime} 79^{\prime \prime} \mathrm{N}, 18^{\circ} 24^{\prime} 52^{\prime \prime} \mathrm{E}$ and locality $2-43^{\circ} 11^{\prime} 57^{\prime \prime} \mathrm{N}, 18^{\circ} 24^{\prime} 07^{\prime \prime} \mathrm{E}$ ) and

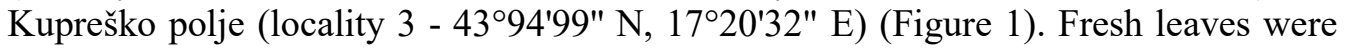
separated immediately into paper bags and stored at $-20^{\circ} \mathrm{C}$. 


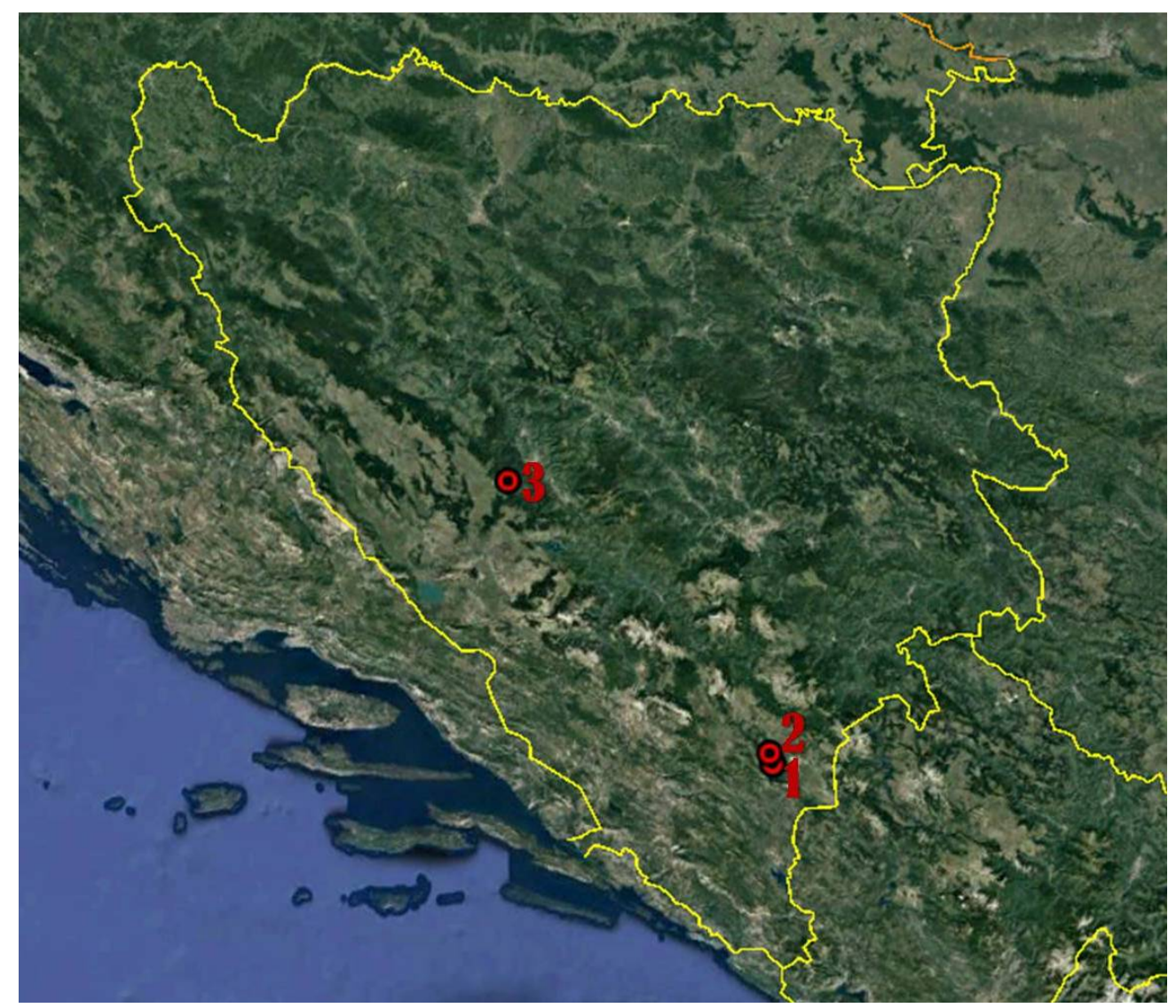

Picture 1. Geographical display of sampling regions

Slika 1. Geografski prikaz lokaliteta na kojima je izvršeno uzorkovanje

To avoid putative interrelationships between the specimens, the distance between sampled individuals was $30 \mathrm{~m}$. Vouchers of sampled individuals were deposited in the Institute of Genetic Engineering and Biotechnology, University of Sarajevo (HM_0515, HM_3515, HM_1715).

\section{DNA extraction- Izolacija DNK}

Frozen and fresh plant tissue was used for DNA extraction (ca. 10-20 mg per sample). Leaves were grounded using mortar and pestle, and transferred to $1.5 \mathrm{ml}$ tubes. Total plant DNA was extracted using modified CTAB procedure (PADMALATHA ET AL., 2008). After extraction, genomic DNA was analyzed by electrophoresis on a $1.5 \%(\mathrm{w} / \mathrm{v})$ agarose gel in 1x SB (Sodium borate) buffer, pH8 (BRODY ET KERN, 2005) and visualized under UV light after staining with Midori green (Nippon Genetics Europe). 


\section{Molecular markers - Molekularni markeri}

For the purpose of genetic characterization trn $\mathrm{L}$ region of chloroplast DNA, matK, ITS1 and ITS2 were observed.

Amplification of $\operatorname{trnL}$ (UAA) intron was performed using primers decribed by TABERLET ET AL. (1991) in $15 \mu 1$ reactions consisting of $1 \mu 1$ of template DNA, $2 \mathrm{mM}$ Tris- $\mathrm{HCl}(\mathrm{pH} 8.0), 10 \mathrm{mM} \mathrm{KCl}, 0.2 \mu \mathrm{M}$ of each primer, $0.2 \mathrm{mM}$ dNTPs, $2.5 \mathrm{mM}$ $\mathrm{MgCl}_{2}$ and 1 unit of Taq DNA polymerase (Gdansk). PCR amplification was carried out in 30 cycles, $45 \mathrm{~s}$ denaturation at $95^{\circ} \mathrm{C}, 30 \mathrm{~s}$ annealing at $51^{\circ} \mathrm{C}, 45 \mathrm{~s}$ extension at $72^{\circ} \mathrm{C}$ and 10 min final extension at $72^{\circ} \mathrm{C}$. Afterwards, amplified trnL (UAA) intron was digested with the restriction enzymes (Taq I, HpyF31, Hinf I, Hind III, Hind II, Rsa I, EcoR I, Ava II, Ban I and Alu I), in order to create enzymatic profiles.

The plastid region of maturase K gene was amplified using 390F and 1440R primers according to FIOR ET AL. (2006). Amplification was performed in $35 \mu 1$ reactions consisting of $1 \mu \mathrm{l}$ of template DNA, $2 \mathrm{mM}$ Tris- $\mathrm{HCl}(\mathrm{pH} 8.0), 10 \mathrm{mM} \mathrm{KCl}$, $0.2 \mu \mathrm{M}$ of each primer, $0.2 \mathrm{mM}$ dNTPs, $2.5 \mathrm{mM} \mathrm{MgCl}_{2}$ and 1 unit of Taq DNA polymerase (Gdansk). PCR parameters were $1 \mathrm{~min}$ denaturation at $94^{\circ} \mathrm{C}, 30 \mathrm{~s}$ annealing at $48^{\circ} \mathrm{C}, 1 \mathrm{~min}$ extension at $72^{\circ} \mathrm{C}, 8 \mathrm{~min}$ final extension at $72^{\circ} \mathrm{C}$ with the total of 26 cycles.

The nuclear regions ITS1 and ITS2 (internal transcribed spacers 1 and 2) fragments were amplified in separate reactions using primers described by WHITE ET AL. (1990). PCR reactions were performed under the same chemical regime as for the matK. PCR amplification was carried out in 30 cycles, 30 s denaturation at $95^{\circ} \mathrm{C}, 30 \mathrm{~s}$ annealing at $50^{\circ} \mathrm{C}, 1 \mathrm{~min}$ extension at $72^{\circ} \mathrm{C}$ and $10 \mathrm{~min}$ final extension at the same temperature.

PCR products were sequenced by Macrogen Inc. Europe as part of their regular capillary DNA sequencing services. MatK, ITS1 and ITS2 amplicons were sequenced only in forward direction.

\section{Plastidial matK and ITS Sequence Assembly, Alignment and Annotation - Uredivanje, poravnanje i anotacija hloroplastne matK i ITS sekvenci}

Plastidial matK and nrDNA sequence identification analyses from Helleborus multifidus were performed against the FASTA program (PEARSON, 1994). BLAST network service (BENSON ET AL., 2003) in GenBank at NCBI was used for final sequence identification, searching for the best identity and similarity scores in local databases. Sequencing reads were assembled using DNASTAR's Lasergene software EditSeq (BURLAND, 2000) and examined manually by electropherograms for sequencing errors. Multiple sequence alignment analyses for two matK and four nrDNA sequences (ITS1 and ITS2) were performed using ClustalW Ver.1.6 (THOMPSON ET AL., 2011) under default parameters. MSA analyzed sequences and outputs were optimized using Jalview 2.9.0b2 (WATERHOUSE ET AL., 2009) and edited by Bioedit v5.09 (HALL, 1999). Two partial matK and four nrDNA consensus 
sequences were deposited in the GenBank database (GenBankID's: KY908380, KY908381, KY908382, KY908383, KY908384, KY908385).

\section{RESULTS AND DISCUSSION - Rezultati i diskusija}

High quality DNA was successfully yielded from all 110 collected samples. The $\operatorname{trnL}$ (UAA) intron was also successfully amplified and digested with ten different enzymes. Six of them (i.e. Taq I, Hinf I, Hind II, AvaII, Rsa I, Alu I) showed restriction activity. However, based on the fragment size data, it was noticed that samples in all of the populations have the same enzymatic profile for all six applied enzymes (Figure 2). Consequently, no intra- or interpopulation polymorphism was detected. This may be due to the inadequacy of applied markers, which are probably not sufficiently sensitive for the detection of genetic diversity within this taxon.

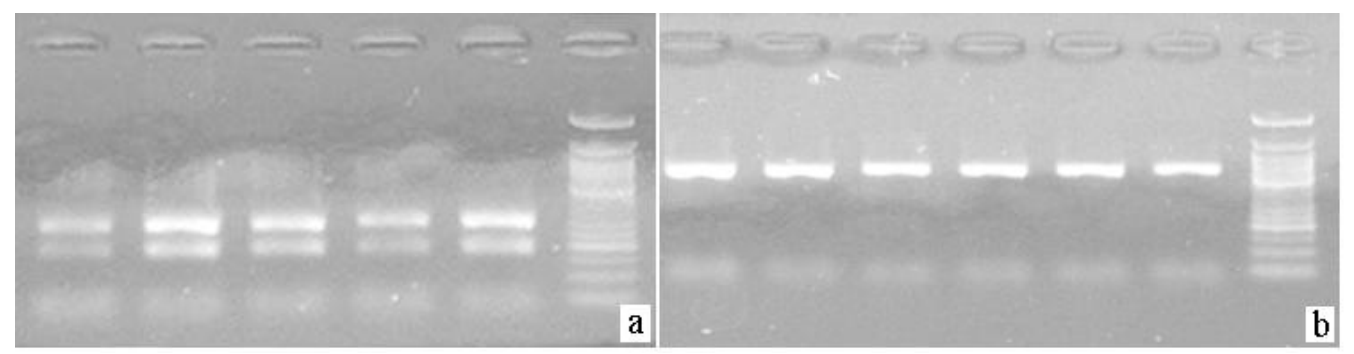

Figure 2. Enzymatic profiles generated by Rsa I (a) and Ava II (b) enzymes Slika 2. Enzimatski profili generirani primjenom Rsa I (a) i Ava II (b) enzima

Maturase K sequences (average length 870bp) from five Helleborus multifidus samples (from three localities) were successfully sequenced and analyzed for discriminatory power. It was found that two out of five matK sequences of the samples were not identical (Figure 3). Estimation of nucleotide diversity showed two polymorphic sites within $m a t K$ with an average $\mathrm{p}$ value of 0.001 (Table 1). 


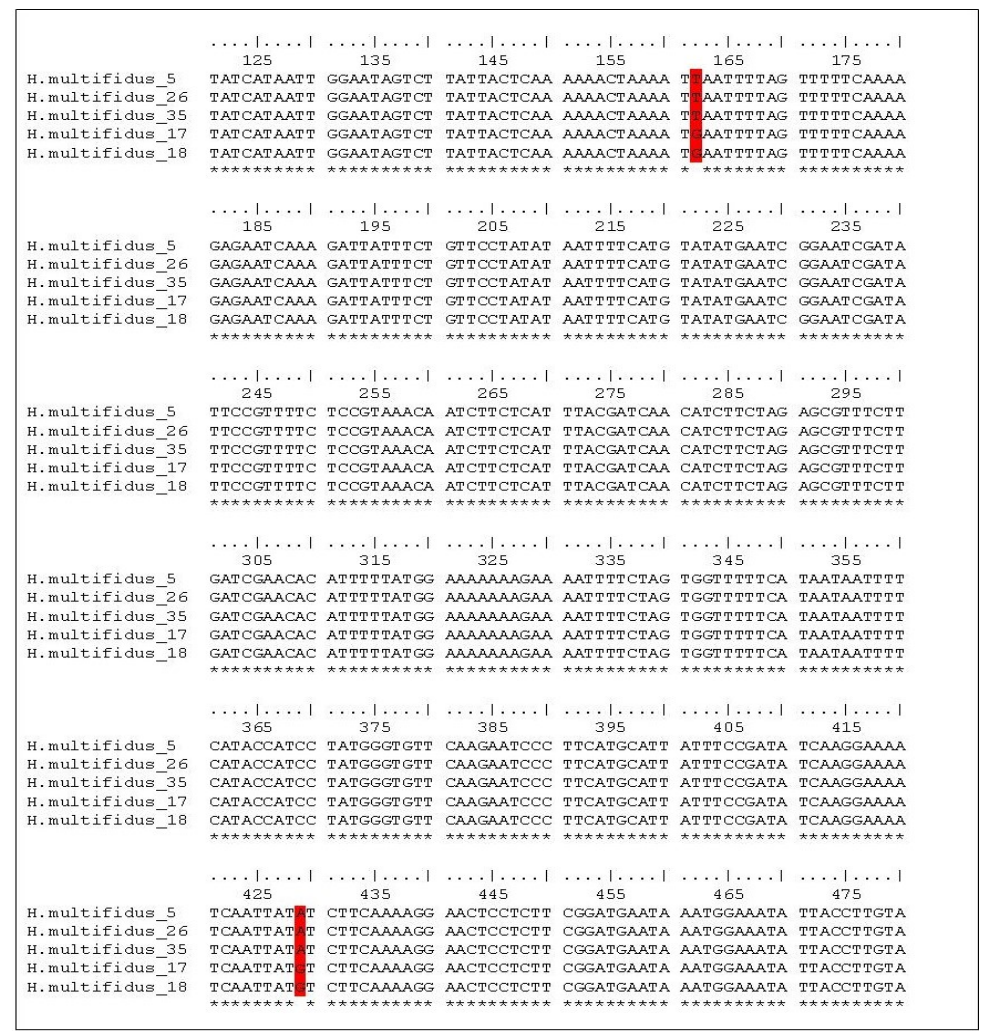

Figure 3. MatK sequence region (120bp-480bp) with two highlited nucleotide polymorphisms Slika 3. Region sekvence matK (120bp-480bp). Dva polimorfna nukleotidna mjesta su naglašena

Table 1. Estimates of nucleotide distance (p) between matK sequences of five hellebore samples

Tabela 1. Procjena nukleotidne distance (p) matK sekvenci za pet uzoraka

\begin{tabular}{l|llll} 
H.multifidus_5 & & & & \\
H.multifidus_26 & 0,000 & & & \\
H.multifidus_35 & 0,000 & 0,000 & & \\
H.multifidus_17 & 0,002 & 0,002 & 0,002 & \\
H.multifidus_18 & 0,002 & 0,002 & 0,002 & 0,000
\end{tabular}

Four sample sequences for internal transcribed spacer 1 (ITS1, average length $260 \mathrm{bp}$ ), and three sequences for internal transcribed spacer 2 (ITS2, average length $310 \mathrm{bp}$ ) were successfully sequenced and annotated. Discriminatory power analyses were performed in order to reveal the resolution of this molecular marker. Two polymorphic sites were found within ITS1 sequence (Figure 4), while only one 
nucleotide polymorphism was found within ITS2 sequence (Figure 5). Estimation of ITS1 and ITS2 nucleotide diversity showed non-identical sequences with an average $\mathrm{p}$ value of 0.007 (Table 2) and 0.002 (Table 3), respectively.

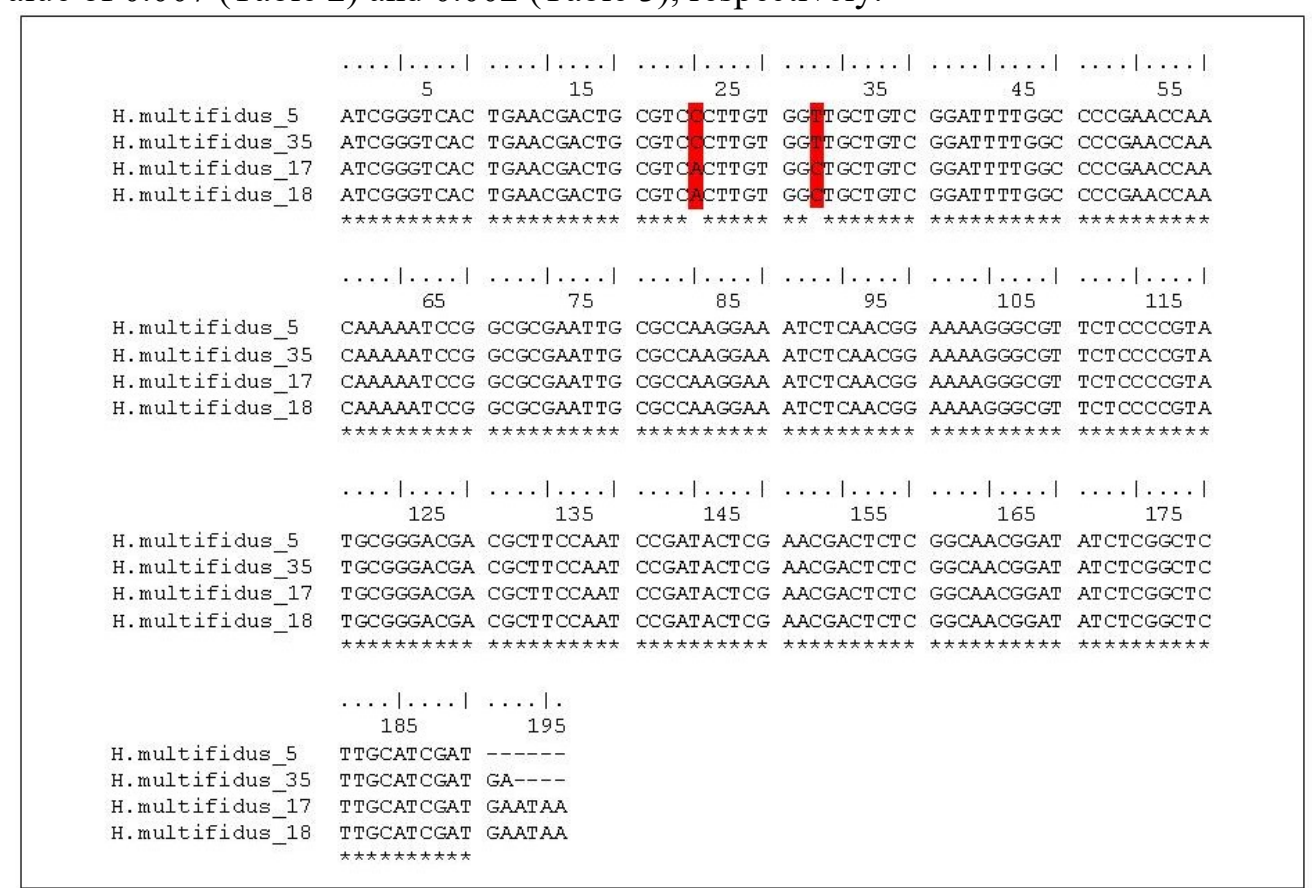

Figure 4. Complete ITS1 sequence region with two highlited nucleotide polymorphisms Slika 4. Kompletan region sekvence ITS1. Dva polimorfna nukleotidna mjesta su naglašena

Table 2. Estimates of nucleotide distance (p) between ITS1 sequences of four hellebore samples

Tabela 2. Procjena nukleotidne distance (p) ITS1 sekvenci za četiri uzorka

\begin{tabular}{l|lll} 
H.multifidus_17 & & & \\
H.multifidus_18 & 0,000 & & \\
H.multifidus_5 & 0,011 & 0,011 & \\
H.multifidus_35 & 0,011 & 0,011 & 0,000
\end{tabular}




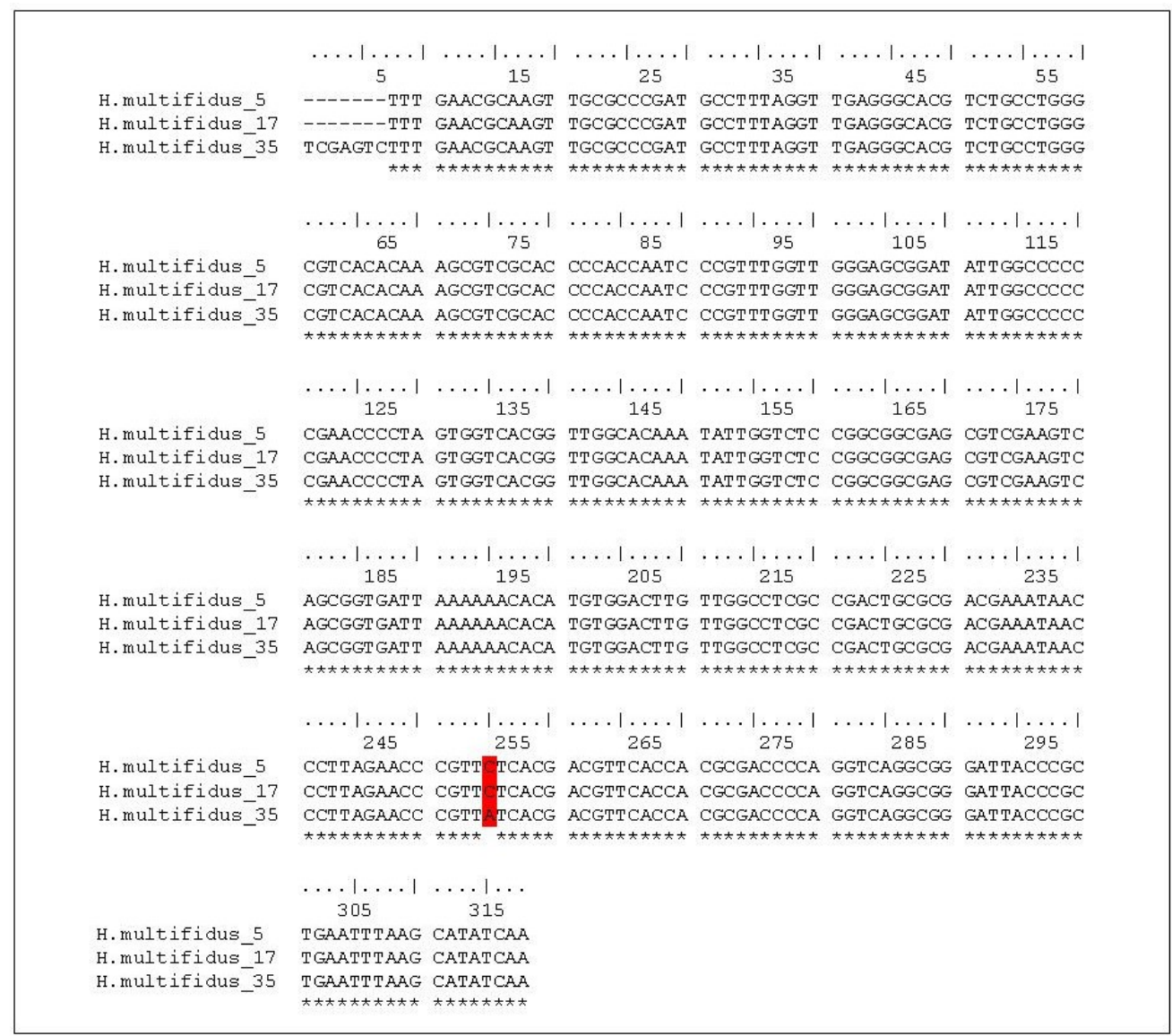

Figure 5. Complete ITS2 sequence region with a single highlited nucleotide polymorphism Slika 5. Kompletan region ITS2 sekvence sa jednim naglašenim nukleotidnim polimorfizmom

Table 3. Estimates of nucleotide distance (p) between ITS2 sequences of three hellebore samples

Tabela 3. Procjena nukleotidne distance (p) ITS2 sekvenci za tri uzorka

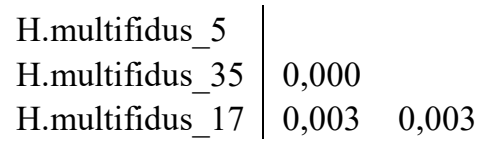

Clearly, the samples from locality 3 (H.multifidus_17 and H.multifidus_18) form a cluster according to matK and ITS1 molecular markers (not a single nucleotide polymorphism was found), while the samples from locality 1 (H.multifidus_5) and locality 2 (H.multifidus_35 and H.multifidus_26) are grouped into the other cluster 
according to matK sequences. A third cluster is formed by H.multifidus_5 and H.multifidus 35 based on nrDNA sequences. These results indicate evident interpopulation differences. This could be attributed to the fact that populations from Trebinje region do not belong to the same taxon in order to the samples from Kupreško polje. Also, the geographic distance and spatial isolation between the studied populations could be the result of nucleotide variation. It is important to emphasize that localities 1 and 2 were previously described by MARTINIS (1793) as a locus classicus for Helleborus hercegovinus. Also, ZONNEVELD (2001) allocated $H$. hercegovinus as a subspecies of $\mathrm{H}$. multifidus, based on the genome size analyses (Cvalue). Most recent studies conducted by MEINERS ET AL. (2011) singled it out as a separate species (H. hercegovinus) based on the amount of nuclear DNA and the multi-locus AFLP data. On the other hand, the Catalogue of life (Roskov ET AL., 2017) does not recognize $H$. hercegovinus as a distinct species, but rather as a subspecies.

Evidently many uncertainties are present in taxonomic status of $H$. multifidus. Although analyses of ITS1, ITS2 and matK molecular markers conducted in this study were not informative for clarifying taxonomic status of species, our results indicate the differences that require further research.

\section{CONCLUSIONS - Zaključci}

The aim of the present study was to provide an insight in molecular-genetic characterization of Helleborus multifidus Vis. in Bosnia and Herzegovina. The results revealed that PCR-RFLP on trnL intron was not informative for testing interpopulation or intrapopulation diversity within analyzed taxon. However, matK, ITS1 and ITS2 sequences pointed out the existence of differences between tested samples, indicating the differences between the populations from Trebinje region and Kupreško polje.

Further molecular-genetic analyses and designed sampling are necessary for molecular-genetic characterization of hellebore species in Bosnia and Herzegovina and adjacent regions to resolve their relationships.

\section{REFERENCES - Literatura}

Benson, D.A., Karsch-MizRachi, I., Lipman, D.J., Ostell, J. \& WheeleR, D.L. (2003): GenBank. Nucleic Acids Res., 31, 23-27.

BRODY, J.R., KERN, S.E. (2005): Sodium boric acid: a Tris-free, cooler conductive medium for DNA electrophoresis. Biotechniques, 38(1), 60.

BURLAND, T.G. (2000): DNASTAR's Lasergene sequence analysis software. Methods Mol Biol., 132, 71-91.

FIOR, S., KARIS, P.O., CASAZZA, G., MinUto, L., SALA, F. (2006): Molecular phylogeny of the Caryophyllaceae (Caryophyllales) inferred from chloroplast matK and nuclear rDNA ITS sequences. Am J Bot, 93(3), 399-411. 
HALL, T. A. (1999): BIOEDIT: a user-friendly biological sequence alignment editor and analysis program for Windows 95/98/NT. Nucleic Acids Symp Ser, 41, 95-98.

MARTINIS, Z. (1973): Genus: Helleborus L. U: Martinis Z., Regula-Berilacqua Lj., Trinajstić I. (Eds.) (1973): Genus: Helleborus. Suppl. Fl. Anal. Jugosl., 1(2): 235-240.

MAtHeW, B. (1989): Hellebores. Alpine Garden Society, St. John's Woking, Surrey, UK.

Meiners, J., Debener, T., Schweizer, G., Winkelmann, T. (2011): Analyisis of the taxonomic subdivision within the genus Helleborus by nuclear DNA content and genome-wide DNA markers. Sci. Hort., 128: 38-47.

Padmalatha, K., Jayaram, K., Prasad, M.N.V. (2008): A Rapid Protocol for the Isolation of Polysaccharide- and Polyphenolic-Free Genomic DNA for RAPD Analysis of Threatened Medicinal Plants. Med. Aromat. Plant Sci. Biotechnol., 2, 50-53.

PEARSON, W.R. (1994): Using the FASTA program to search protein and DNA sequence databases. Methods Mol Biol, 24, 307-31.

Roskov Y., Abucay L., ORRell T., Nicolson D., Bailly N., KIRK P.M., Bourgoin T., DeWalt R.E., Decock W., De Wever A., Nieukerken E. Van, Zarucchi J., Penev L., eds. (2017). Species 2000 \& ITIS Catalogue of Life, 22nd March 2017. Digital resource at www.catalogueoflife.org/col. Species 2000: Naturalis, Leiden, the Netherlands. ISSN 2405-8858

SUN, H., MCLEWIN, W., FAY, M.F. (2001): Molecular phylogeny of Helleborus (Ranunculaceae), with an emphasis on the East Asian-Mediterranean disjunction. Taxon, 50, 1001-1018.

ŠILIĆ, Č. (1990): Endemične biljke. Svjetlost, Sarajevo. pp. 36.

Taberlet, P., Gielly, L., Pautou, G., Bouvet, J. (1991): Universal primers for amplification of three noncoding regions of chloroplast DNA. Plant Mol. Biol., 17, 1105-1109.

ThOMPSON, J. D., HIGgINS, D.G., GIBSON, T. J. (2011): CLUSTAL W: improving the sensitivity of progressive multiple sequence alignment through sequence weighting, positions-specific gap penalties and weight matrix choice. Nucleic Acids Res. 22(22), 4673-4680.

TUtin, T.G. (1996): Genus Helleborus L. In: Tutin T.G., Burges N.A, Chater A.O., Edmondson J.R., Heywood V.H., Moore D.M., Valentine D.H., Walters S.M., Webb D.A. (Eds.) (1996): Flora Europaea, vol 1. Cambridge: Cambridge Univ. Press, pp. 249-251.

Waterhouse, A.M., Procter, J.B., Martin, D.M.A., Clamp, M., Barton, G.J. (2009): Jalview Version 2-a multiple sequence alignment editor and analysis workbench. Bioinformatics, 25, 1189-1191.

WHITE, T.J., BRIMS, T., LEE, S., TAYLOR, J. (1990): Amplification and direct sequencing of fungal ribosomal RNA genes for phylogenetics. In „PCR Protocols: A Guide to Methods and Applications" (M. Innis, D. Gelfand, J. Sninsky, and T. White, Eds.), pp. 315-322, San Diego: Academic Press. 
ZonNeVELD, B.J.M. (2001): Nuclear DNA contents of all species of Helleborus (Ranunculaceae) discriminate between species and sectional division. Plant Syst. Evol., 229: 125-130.

\section{SAŽETAK}

H. multifidus je endemična ilirsko-jadranska vrsta rasprostranjena u Italiji, Sloveniji, Hrvatskoj, Bosni i Hercegovini, Crnoj Gori i Albaniji. Iako nekoliko studija navodi različite taksonomske kategorije za $H$. multifidus, prvi put su korišteni molekularnogenetički markeri (trnL region hloroplastne DNA, matK, ITS 1 i ITS 2) u genetičkoj karakterizaciji populacija $H$. multifidus sa tri lokaliteta u Bosni i Hercegovini. Rezultati provedenog istraživanja su pokazali da PCR-RFLP metoda trnL introna nije informativna $u$ utvrđivanju interpopulacijskog $\mathrm{i}$ intrapopulacijskog diverziteta analiziranog taksona. Međutim, sekvence matK, ITS1 i ITS2 ukazuju na postojanje razlika između populacija kukurjeka iz okoline Trebinja i populacija sa Kupreškog polja, ukazujući na nužnost dodatnih analiza.

Corresponding author: Lejla Lasić,University of Sarajevo - Institute for Genetic Engineering and Biotechnology, Zmaja od Bosne 8 (Kampus), Sarajevo Bosna\&Herzegovina, email: lejla.lasic@ingeb.unsa.ba 